\title{
Bimbingan Konseling dalam Peningkatan Kualitas Belajar Mahasiswa Perguruan
}

\section{Tinggi Islam Negeri}

\author{
Imron Mustofa ${ }^{1}$, Moch. Kalam Mollah ${ }^{2}$ \\ ${ }^{1}$ Universitas Islam Negri Sunan Ampel Surabaya, ${ }^{2}$ Institut Teknologi Adhi Tama \\ Surabaya \\ 1imron_mustofa@uinsby.ac.id, ${ }^{2}$ kalam@itats.ac.id
}

\begin{abstract}
Social pressure and great desire to take education at level of the State Islamic University (PTAIN) has given rise to several challenges. This paper elaborates some problems experienced by students of PTAIN. This paper approach is field research with literature data (library research) as support material. The paper concludes college has unique characteristics, self-reliance and mental-spiritual balance. In progress, there are two problems faced by students of PTAIN: personal and social issues (non-academic). Both come down to mindset and mental conditions. They give depth impact on life management, adjustments to academic world, environment and society. Not a few students experience introvert attitude and new environment makes them uncomfortable, eventually lead to saturation.
\end{abstract}

Keywords: Introvert; Self Intelligence; Trichomis; Sanguinis.

\begin{abstract}
Abstrak
Tekanan sosial dan keinginan besar menempuh pendidikan ke jenjang Perguruan Tinggi Agama Islam Negeri (PTAIN) melahirkan beberapa tantangan tersendiri. Tulisan ini hadir guna mengelaborasi beberapa persoalan yang dialami oleh mahasiswa PTAIN. Kajian ini berdasar pada penelitian lapangan dengan dukungan data literatur atau penelitian kepustakaan. Kajian ini menyimpulkan bahwa perguruan tinggi memiliki ciri khas tersendiri, yang berupa kemandirian dan keseimbangan mental-spiritual. Dalam perkembangannya, setidaknya ada dua permasalahan yang terjadi pada mahasiswa PTAIN: persoalan pribadi dan sosial (non-akademik). Kedua masalah tersebut bermuara pada pola pikir dan kondisi kejiwaan. Keduanya sangat berpengaruh terhadap kualitas pengelolaan kehidupan individu, penyesuaian terhadap dunia akademis, lingkungan dan masyarakat. Tidak sedikit mahasiswa mengalami sikap introvert dan lingkungan baru membuatnya tidak nyaman yang akhirnya menimbulkan jenuh.
\end{abstract}

Kata Kunci: Introvert; Kecerdasan Diri; Trichomis; Sanguinis. 


\section{Pendahuluan}

Menempuh pendidikan hingga ke jenjang yang lebih tinggi merupakan impian setiap orang. Tentu nya impian tersebut didasari oleh keinginan yang besar guna menggapai sesuatu. Dari impian tersebut, timbullah keinginan seseorang untuk melanjutkan pendidikannya yang tidak sebatas berhenti di bangku Sekolah Menengah saja. Mereka berusaha untuk bagaimana caranya agar sampai kepada impian tersebut. Bagaimana caranya agar bisa duduk di bangku perkuliahan. Memikirkan dan berusaha bagaimana impian tersebut bisa terwujud, dan sesuatu yang hendak dicapai pun bisa diraih. Karena pada dasarnya, pendidikan yang tinggi tidak hanya bertujuan untuk mengubah kepribadian diri seseorang menjadi seorang akademisi maupun ilmuwan, akan tetapi sejatinya pendidikan yang tinggi bertujuan untuk membantu masyarakat dalam membentuk tatanan hidup yang berkembang dan maju. Saat ini masyarakat dan dunia membutuhkan seseorang yang bisa memberikan kontribusi yang besar untuk terciptanya kehidupan yang lebih beradab.

Bagaimanapun, impian harus selaras dengan keinginan. Seseorang bisa mencapai apa yang dituju karena pada dasarnya memang ia menginginkan hal tersebut. Jalan yang digunakan pun memang jalan yang mampu untuk ditempuh. Jalan yang dilalui pun sesuai dengan apa yang tergambar di pikiran. Sama halnya dengan seseorang yang memimpikan menempuh pendidikan yang tinggi, menginginkan memasuki perguruan tinggi dan menimba ilmu di bangku perkuliahan guna menyelesaikan gelar sarjana, master maupun doktor. Ia senantiasa menimbang dengan matang bagaimana kemampuan dan keinginan yang ia miliki. Namun apakah bisa apabila impian tersebut tidak selaras dengan keinginan? Apakah bisa tercapai sebuah perubahan apabila jalan yang kita lalui pun tidak sesuai dengan kemampuan dan keinginan yang kita miliki? Lingkungan yang berbeda dengan diri kita pun menjadi faktor yang dapat menghambat tumbuh kembang pemikiran kita. Lantas, apakah semua kemajuan dalam diri kita terbentuk karena rasa ingin dan nyaman atas lingkungan yang kita hadapi?

Problematika ini yang sering menghantui mahasiswa-mahasiswa Institut Agama Islam maupun mahasiswa Universitas Islam Negri. Tuntutan sosial dan impian untuk menjadi sarjana dan seseorang yang memiliki pendidikan yang lebih tinggi membuat mereka mengerahkan segala upaya dan usaha agar sampai kepada yang dituju. Salah satu upaya tersebut adalah mengikuti seleksi beberapa jalur penerimaan mahasiswa dengan berbagai syarat dan ketentuan khusus bagi yang hendak mendaftar. Beberapa jalur tersebut yang kemudian menjadi jembatan bagi mereka yang hendak meneruskan impian 
untuk bisa sampai ke perguruan tinggi. Tentunya tidak hanya ratusan pendaftar dengan niat yang sama, akan tetapi ribuan bahkan puluhan ribu yang memiliki niat dan impian yang sama.

Impian untuk menjadi seseorang yang bermanfaat bagi orang lain tentunya mendorong seseorang tersebut untuk menuntut ilmu yang nantinya dibutuhkan masayarakat umum. Kebutuhan masyarakat salah satunya ialah adanya seorang akademisi yang mumpuni dalam bidang keagamaan. Di sinilah letak pentingnya Perguruan Tinggi Agama Islam Negeri (PTAIN)/ Perguruan Tinggi Agama Islam Swasta (PTAIS), tujuan terbentuknya PTAIN/PTAIS adalah menginginkan generasi-generasi mahasiswa yang menempuh pendidikan di tempat tersebut menjadi seorang akademisi yang tidak merugikan masyarakat dengan "mal-praktik" keilmuannya. Memang betulbetul dibentuk untuk memiliki modal keagamaan yang kuat, sehingga calon mahasiswa yang mendaftar di PTAIN/PTAIS hendaknya memiliki modal kemampuan, keinginan, mental yang kuat dan pastinya kepercayaan diri yang besar. Karena jika kita lihat bahwa pendaftar PTAIN/PTAIS tidak hanya dari latar belakang siswa/siswi yang sebelumnya sedikit banyak bermodalkan ilmu agama, maupun mereka yang memang alumni pesantren. Banyak sekali mahasiswa yang dari latar belakang sekolah umum, dengan kata lain alumni SMA Negri maupun swasta, yang sejatinya tidak terlalu fokus pada kajian agama. Mereka memilih PTAIN/PTAIS sebagai tempat kelanjutan untuk studinya. Pada dasarnya setiap mahasiswa/i memiliki keinginan yang sama, yaitu lulus pada jalur yang dipilih. Namun terkadang optimis ini hanya bertumpu pada kelulusan saja. Akibatnya meskipun lulus, tidak sedikit yang merasa tidak pas atau bahkan tidak mampu melanjutkan studi pada jurusan yang dipilih. Tak heran apabila kita melihat fakta bahwa beberapa di antara mahasiswa yang telah terjun ke dunia PTAIN mengalami kesulitan dalam menghadapi matakuliah yang mereka laksanakan.

\section{Metode}

Penelitian ini berfokus pada kajian kontekstual lapangan mengenai persoalan yang dihadapi oleh mahasiswa perguruan tinggi keagamaan Islam. Ia mengkhususkan fokus pada kendala-kendala yang dihadapi selama menempuh pendidikan di perguruan tinggi. Pendekatan yang dipergunakan adalah pendekatan studi kasus (fenomenologi) dengan data utamanya dari wawancara dengan narasumber dan didukung oleh beberapa sumber tertulis, baik berupa buku, artikel jurnal maupun karya lain semisalnya. 


\section{Temuan dan Diskusi}

\section{Fungsi dan Peranan PTAIN}

Terbentuknya Perguruan tinggi keislaman semacam Institut Agama Islam Negeri (IAIN) tidak lain karena memiliki harapan tersendiri akan terbentuknya generasi penerus yang mumpuni dalam bidang Tarbiyah, Ushuludin, Syari'ah, Dakwah serta Adab. Generasi penerus ini diharap akan menjalankan peran keagamaan dalam membimbing, mengarahkan serta mendorong kepada perkembangan sosial masyarakat sebagai salah satu upaya membangun negeri yang lebih baik. Fungsi dan peranan ini tentunya terjadi karena suatu kesempatan yang mereka hadapi seperti kesempatan dalam pengabdian masyarakat yang dilakukan secara organisatoris dan individualis. ${ }^{1}$

IAIN memiliki kebijakan yang ditempuh di dalam melakukan pengabdian masyarakat dengan memperhatikan kebutuhan masyarakat, serta fungsi dan peranan agama dalam mendorong mengendalikan perubahan sosial. Hal ini tentu saja diaplikasikan dalam berbagai kegiatan yang ada. Menurut Departemen Agama Republik Indonesia, peran dan fungsi yang dimainkan oleh IAIN sebagai satu satu penyelenggara pendidikan tinggi keislaman mencakup beberapa hal: Pertama, minimal setiap tahunnya IAIN sebagai lembaga pendidikan mampu menghasilkan para sarjana yang memiliki kualifikasi inteletualitas dan pemahaman keagamaan yang cukup mumpuni. Kemampuan ini pada akhirnya, akan mendorong para alumni untuk mampu membaur sekaligus mengintegrasikan diri ke dalam setiap lini kehidupan baik di tingkat pemerintahan maupun kehidupan masyarakat secara luas. ${ }^{2}$

Kedua, peran institusi perguruan tinggi melalui pelbagai kegiatan pengajaran, penelitian dan pengabdian masyarakat akan mendorong terjadinya perubahan masyarakat untuk lebih maju dan berdaya saing. Perlunya meneliti perkembangan dan perubahan ini dirasa perlu, karena perubahan dalam masyarakat merupakan sesuatu yang tidak mungkin untuk dihindari. Meskipun demikian, melalui tiga tugas pokok perguruan tinggi tersebut setidaknya IAIN akan mampu beradaptasi sekaligus menyediakan kebutuhan masyarakat dalam rangka menghadapi perubahan yang semakin cepat. Peran perguruan tinggi menjadi semakin terasa, terutama dalam menyikapi perubahan dengan menghadirkan solusi yang tepat dan efisien berupa pemahaman nilai-nilai kemasyarakatan dengan tetap berpegang pada fondasi dasar keislaman yang baku tentunya yang bersumber dari ajaranajaran agama Islam. Proses pembahasan, penelisikan sekaligus pemecahan solutif

${ }^{1}$ Charles Michele Stanton, Pendidikan Tinggi Islam (Jakarta: Logos, 1998), 63-64.

${ }^{2}$ Departemen Agama Republik Indonesia, Sejarah Institusi Agama Islam Negeri (IAIN), 220-222.

Indonesian Journal of Islamic Education Studies (IJIES)

Volume 2, Nomor 2, Desember 2019 
terhadap pelbagai persoalan keagamaan dihadirkan oleh institusi perguruan tinggi keagamaan Islam. ${ }^{3}$

Ketiga, melalui aktivitas pengabdian kepada masyarakat yang dijalankan oleh seluruh civitas pendidikan dari unsur pegawai, dosen dan mahasiswa setiap tahunnya, IAIN mampu menghadirkan peran sekaligus dampak yang cukup signifikan terhadap perkembangan masyarakat. Salah satu bentuk aktivitas pengabdian ini dilakukan oleh seluruh mahasiswa perguruan tinggi keagamaan Islam dalam bentuk Kuliah Kerja Nyata $(\mathrm{KKN})$. KKN sejatinya merupakan satu aktivitas yang dilakukan IAIN sebagai bentuk kegiatan edukasi mahasiswa sekaligus masyarakat yang diimplementasikan dalam pelbagai kegiatan seperti: penyuluhan dan pendidikan masyarakat dalam satu persoalan tertentu. $^{4}$

Hadirnya peran dan fungsi perguruan tinggi keagamaan Islam yang dilakukan IAIN, Sekolah Tinggi Agama Islam Negeri (STAIN) maupun Universitas Islam Negeri (UIN) secara tidak langsung telah menyuguhkan satu usaha memperbaiki sekaligus menyediakan sumber daya manusia yang bermutu tinggi. Mukti Ali saat menjabat sebagai Menteri Agama Republik Indonesia pernah nyatakan bahwa STAIN, IAIN dan UIN memainkan peran yang sangat signifikan terhadap perkembangan masyarakat di Indonesi, meskipun demikian besarnya tanggung jawab tersebut juga diiringin dengan hadirnya beberapa kelemahan yang harus diperhatikan oleh seluruh unsur masyarakat dan pemerintah. Setidaknya ada beberapa kelemahan yang harus diberi perhatian lebih yang berkaitan dengan lembaga pendidikan tinggi ini, seperti: pertama, lemahnya sistem maupun metode-metode yang dimiliki oleh perguruan tinggi dalam menjalankan tugasnya. Kedua, minimnya mentalitas keilmuan yang dimiliki oleh unsur-unsur yang berkaitan dengan perguruan tinggi. Ketiga, lemahnya penguasaan bahasa asing baik itu Arab selaku bahasa kajian dalam Islam maupun Inggris sebagai bahasa komunikasi internasional..$^{5}$ Berdasar berbagai kelemahan tersebut, maka perlu dihadirkan suatu perbaikan. Proses ini dapat dilakukan setidaknya melalui pengkajian sekaligus perbaikan terhadap nilai-nilai dasar maupun garis-garis besar pembinaan perguruan tinggi keislaman. Aspek-aspek yang perlu diperhatikan dalam perbaikan tersebut mencakup minimal tujuh elemen, seperti: tata kelola organisasi, kesesuaian kurikulum, personil

\footnotetext{
${ }^{3}$ Imron Mustofa, "Gagasan Islamisasi Ilmu (Studi tentang kerangka metodologi Institute for the Study of Islamic Thought and Civilization (INSISTS))", (Disertasi---UIN Sunan Ampel Surabaya, 2019), 83-85.

${ }^{4}$ Mustofa.

${ }^{5}$ Mustofa, 216-217.
} 
pengajar maupun tenaga kependidikan, materil, pembiayaan, penelitian dan persoalan kemahasiswaan. ${ }^{6}$

Menghadapi era global yang tentunya dengan berbagai tuntutan yang semakin berkembang, maka STAIN maupun IAIN dalam kemajuan berikutnya sebagian telah berubah menjadi Universitas Negeri Islam (UIN). Telah tercatat sejak tahun 2002 sampai tahun 2012 setidaknya telah ada enam IAIN yang berkembang menjadi UIN. Di antaranya: UIN Sunan Kalijaga Yogyakarta, UIN Sunan Ampel Surabaya, UIN Syarif Hidayatullah Jakarta, UIN Alauddin Makassar, UIN Sunan Gunung Jati Bandung dan UIN Sultan Syarif Pekanbaru. Dengan terbentuknya UIN maka pengembangan ilmu pun menjadi semakin bervariasi. Perkembangan zaman juga telah terjadi menjadi penguat UIN dalam mengembangkan diri dalam bidang keilmuan, yang pada awalnya hanya terbatas pada ilmu agama saja, maka saat ini keilmuan tersebut lebih beragam. Hal inilah yang menjadikan Universitas Islam Negeri sangat dibutuhkan untuk keberlangsunga hidup bermasyarakat.

\section{Ragam Permasalahan Mahasiswa}

Seperti yang dijelaskan sebelumnya bahwa, tekanan sosial dan keinginan yang besar untuk menempuh pendidikan ke jenjang yang lebih tinggi membuat banyak lulusan SMA maupun Aliyah berupaya keras guna memasuki perguruan tinggi. Dengan adanya jalur yang banyak dan tidak terlalu memberatkan membuat PTAIN digandrungi banyak orang. Banyaknya pendaftar dari berbagai kalangan dan berbagai latar belakang menghiasi dunia PTAIN. Tidak hanya berbagai kebaikan saja yang turut menghiasi dunia PTAIN, namun ada pula permasalahan yang bahkan tidak terlalu nampak di muka publik. Permasalahan inilah yang dihadapi mahasiswa PTAIN, bukan hanya permasalahan di dalam PTAIN.

Dalam perjalanan kegiatan pengajaran dan pembelajaran, perguruan tinggi memiliki ciri khasnya masing-masing. Tidak seperti lembaga pendidikan di jenjang sebelumnya, proses pendidikan di perguruan tinggi lebih menekankan nilai-nilai kemandirian. Kemandirian yang dimaksud adalah kemandirian dalam pelaksanaan kegiatan belajar mengajar, baik segi kognitif maupun psikomotorik. Mahasiswa dididik untuk mandiri dan dituntut untuk lebih banyak menjalani proses pembelajaran secara terstruktur dan mandiri. Mahasiswa diwajibkan untuk mampu dalam menentukan

\footnotetext{
${ }^{6}$ Mustofa, 237.
} 
sumber-sumber yang menjadi dasar keilmuan. Dengan kemandirian mahasiswa dituntut mampu dan mau mengkaji dan mendalami bahan ajar secara terstruktur, mendalam dan mandiri. Dengan kemandirian mahasiswa, porsi pengawasan, pengendalian dan pengaturan tampak lebih berkurang dibanding dengan para siswa ditingkat sebelumnya. Proses pembelajaran mandiri semacam ini dipandang perlu sebagai dampak dari penilaian bahwa mahasiswa merupakan manusia yang telah cukup dewasa untuk mengelola dirinya sendiri.

Dalam usaha merealisasikan proses pendidikan mandiri itu, tidak sedikit persoalan yang dihadapi oleh mahasiswa, dosen dan seluruh tenaga pendidikan yang terlibat. Kendala itu dapat berupa halangan internal maupun eksternal. Terlepas dari persoalan ini, dalam usaha mengembangkan proses pendidikan perlu kiranya satu bimbingan intensif dan sistematik bagi mahasiswa ataupun pihak lain yang dipandang perlu demi menyediakan solusi dalam menghadapi, mengatasi maupun menghindari persoalan-persoalan itu. Pada bagian ini kita akan lebih membahas rinci mengenai permasalahan-permasalahan mahasiswa PTAIN.

Di sini penulis setidaknya melihat dua permasalahan yang terjadi pada mahasiswa PTAIN. Pertama, persoalan pribadi dan sosial (non-akademik). Permasalahan ini lebih kepada persoalan yang dihadapi mahasiswa dalam pengelolaan kehidupan individu, penyesuaian terhadapa lingkungan dan masyarakat baik yang berkorelasi dengan tempat mukim maupun kehidupan di lingkungan kampus. Di antara beberapa persoalan tersebut adalah penyesuaian diri dengan masyarakat sekitar tempat bermukim, terutama bagi para pendatang, menyesuaikan diri dengan lingkungan PTAIN. Seperti halnya hasil wawancara penulis dengan salah satu eks mahasiswa UIN Sunan Ampel Surabaya, yang mana ia memutuskan untuk berhenti melanjutkan kuliah di UIN Sunan Ampel karena beberapa faktor. Inti dari apa yang beliau sampaikan ialah: untuk berada di jurusan ilmu hadis memang dari awal sedikit ragu, tapi beliau berusaha mencoba terlebih dahulu. Lingkungan yang beliau hadapi tidak sesuai dengan diri narasumber. Narasumber merasa bahwa karakter dirinya ialah seorang yang introvert, dan lingkungan barunya ini membuatnya tidak nyaman. Sehingga untuk belajar pun beliau tidak memiliki semangat tinggi dan merasa jenuh. ${ }^{7}$

Permasalahan pertama ini mencakup problematika non-akademik (sosial/pribadi) yang dihadapi mahasiswa kebanyakan. Hasil wawancara di atas merupakan salah satu

\footnotetext{
${ }^{7}$ Anggi Kiswoyo, Wawancara (Surabaya, 15 Novermber 2019).
} 
contoh dari berbagai fenomena. Di balik permasalahan yang dihadapi narasumber di atas, ada beberapa permasalahan yang penulis rasa perlu dipaparkan. Di antaranya adalah; kesulitan biaya ekonomi, kesulitan dengan permasalahan tempat tinggal, kendala dalam penyesuaian diri baik yang berhubungan dengan masyarakat maupun kondisi lingkungan tempat tinggal yang baru. Adanya kendala dalam menyesualikan diri terhadap lingkungan dan masyarakat muncul sebagai dampak kepribadian diri dan masalah-masalah pribadi yang dialami oleh masing-masing individu.

Lain daripada itu, terdapat pula beberapa mahasiswa yang memaparkan bahwa alasan memilih PTAIN sebagai tempat untuk meniti pendidikan ke jenjang yang lebih tinggi ialah karena keinginan untuk lebih banyak mendalami ilmu agama. Meskipun terdapat berbagai kesulitan yang dihadapi, namun mahasiswa tersebut lebih memilih untuk melanjutkan dan berupaya beradaptasi dengan lingkungan. Ia mengatakan bahwa ada beberapa orang yang mendukungnya di sekitar lingkungan baru tersebut. Hal inilah yang menjadikannya bersemangat untuk mencoba bertahan dalam lingkungan PTAIN yang menurutnya, berbeda dengan kondisi dirinya. ${ }^{8}$

Kedua, persoalan akademis. Kendala ini berkorelasi dengan pelbagai kendala dalam perencanaan, pelaksanaan serta pengoptimalan proses belajar. Di antara beberapa persoalan yang kerap kali muncul adalah kendala dalam mengelola alokasi waktu untuk belajar. Persoalan waktu sejatinya muncul sebagai dampak dari besarnya bebab kewajiban perkuliahan beserta aktivitas lain yang diikuti oleh peserta didik. Persoalan ini juga diperparah dengan minimnya semangat belajar dan kesalhan metode pembelajaran yang dialami oleh mereka. Kurang tepatnya cara belajar memunculmkan berkurangnya rasa keingintahuan dalam memperdalami ilmu dan yang paling sering terjadi adalah permasalahan mahasiswa dalam kesulitan memilih konsentrasi mata kuliah yang sesuai dengan minat dan kemampuan.

Kedua kendala mahasiswa dalam belajar tersebut sebenarnya saling berkesinambungan. Keduanya saling mempengaruhi dan memberikan dampak sebab akibat. Akibat yang ditimbulkan dari sebab ketidak cocokan diri dan lingkungan ialah kesulitan mahasiswa dalam belajar. Hal inilah yang menjadikan permasalahan ini sangat akut. Bagaimana tidak? Mahasiswa PTAIN dituntut untuk benar-benar menguasai ilmu pengetahuan beserta ilmu agamanya. Lulusan PTAIN diharapkan menjadi lulusan yang berbobot, akademisi yang handal, baik dalam bidang pengetahuan maupun bidang agama.

\footnotetext{
${ }^{8}$ Zulfa Permata, Wawancara (Surabaya, 15 November 2019).
} 
Kesulitan belajar ini tidak selalu disebabkan karena faktor inteligensi (IQ) yang rendah (kelainan mental), akan tetapi dapat juga disebabkan oleh faktor-faktor non inteligensi. Dengan demikian, IQ yang tinggi belum tentu menjamin keberhasilan belajar. ${ }^{9}$ Terdapat beberapa faktor yang menjadikan seorang peserta didik mengalami kesulitan belajar. Pertama faktor ekstern peserta didik. Faktor ekstern peserta didik meliputi hal-hal maupun keadaan yang datang dari luar peserta didik. Beberapa faktor tersebut di antaranya, lingkungan perguruan tinggi sekaligus tempat tinggal selama belajar yang kurang kondusif, nyaman serta keadaan keluarga yang kurang mendukung proses pembelajaran serta lingkungan masyarakat yang membuat peserta didik tidak nyaman. ${ }^{10} \mathrm{Kedua}$, faktor intern mahasiswa. Faktor intern merupakan hal-hal atau keadaan yang muncul dari dalam diri mahasiswa sendiri. Persoalan ini menurut penuturan $\mathrm{M}$. Musthofa Huda, dalam karyanya Psikologi Belajar, terbagi menjadi beberapa hal, seperti minimnya bekal keilmuan dasar, kurangnya bakat serta ketiadaan dorongan dalam diri peserta didik.

Minimnya kualitas ataupun bekal mendasar yang diperlukan seorang peserta didik untuk mengenyam pendidikan setingkat perguruan tinggi menjadi salah saru faktor yang paling banyak memunculkan kendala dalam perjalanan proses pendidikan di perguruan tinggi. Pendidikan di perguruan tinggi yang menuntut kemandirian dalam proses pembelajarannya sangat dipengaruhi oleh kemampuan yang disebut inteligensi. Inteligensi merupakan salah satu media utama dalam mencapai keberhasilan dalam proses pembelajaran. Kekurangan dalam inteligensi tidak menutup kemungkinan akan memunculkan persoalan-persoalan lain yang berkaitan dengan kemampuan menalar seorang mahasiswa. Hal ini tentunya akan menjadi hambatan tersendiri dalam perkembangan proses pendidikan. ${ }^{11}$

Meskipun tingkat inteligensi berdampak besar dalam kelangsungan pendidikan seorang mahasiswa, namun ada faktor lain yang juga tidak kalah penting darinya, seperti bakat dan motivasi diri. Sama halnya dengan inteligensi, bakat merupakan salah satu sarana utama dalam dalam menggapai satu tujuan tertentu, tidak terkecuali belajar. Seorang mahasiswa yang minim akan bakat atau bahkan tidak menyadari bakat dirinya, maka barang tentu ia akan mengalami kesulitan dalam proses belajar. Inteligensi dan

\footnotetext{
9 Abu Ahmadi, Ahmadi, Abu, Aziz, Ahmad Amir, Supriyono dan Widodo, Psikologi Belajar (Jakarta: Rineka Cipta, 2004), 77.

${ }^{10}$ M. Musthofa Huda, Psikologi Belajar (Surabaya: UIN Sunan Ampel Pres, 2014), 183-184.

${ }^{11}$ Huda.
} 
bakat akan mempengaruhi minat belajar seorang mahasiswa. Hal ini pada akhirnya akan menentukan keberhasilkan proses pendidikan yang ia tempuh, sebaliknya tanpa keduanya seseorang akan menghadapi pelbagai kesulitan dalam proses pembelajaran. ${ }^{12}$ Terkumpulnya motivasi dan bakat secara tidak langsung akan menghadirkan kepercayaan diri yang baik sebagai bekal seorang mahasiswa dalam menghadapi segala persoalan yang mungkin akan muncul di kemudian hari.

\section{Keterampilan Berpikir dan Kecerdasan Diri}

Salah satu tujuan pendidikan adalah membuat anak berpikir kreatif baik untuk memecahkan masalah maupun untuk bisa berkomunikasi atau menyampaikan pemikiran mereka. Padahal, penerapan pembelajaran tidak mendorong siswa untuk berpikir kreatif. Dua faktor yang menyebabkan pemikiran kreatif tidak berkembang selama pendidikan adalah kurikulum yang pada umumnya dirancang dengan target material yang luas, sehingga pendidik lebih fokus menyelesaikan materi daripada pada metode pengajaran yang dapat meningkatkan kemampuan berpikir.

Peningkatan dalam kualitas berpikir merupakan tujuan bersama dari seluruh sistem pendidikan yang ada. Kualitas berpikir secara tidak langsung telah menjadi satu barometer mutu suatu pendidikan. Oleh karena itu tidak mengherankan kalau suatu proses pembelajaran selalu diarahkan kepada peningkatan keterampilan berpikir. Guna mendukung hal ini, perlu dihadirkan satu metode untuk menyelaraskan tujuan utama dalam proses pendidikan dengan potensi yang ada dalam diri peserta didik. Keselaran dua hal ini menjadi sesuatu yang mutlak ada guna menciptakan satu sistem pendidikan yang efektif dan efisien utamanya dalam mempersiapkan peserta didik merespons segala persoalan yang ia hadapi. Seluruh komponen ini muncul dari proses pembiasan dan pengulangan secara konstan yang poros utamanya terletak pada pola pikir. Dampak lanjutan dari pola pikir ini akan melahirkan cara pandang yang pada gilirannya kelak akan termanifestasikan dalam bentuk karya, perbuatan dan perkataan. ${ }^{13}$ Untuk mengambil contoh, seluruh ilmu pengetahuan apapun objek kajiannya, apakah matematika, sosiologi, kimia maupun kesenian, kesemuanya akan bermuara pada proses berpikir. Meskipun demikian proses berpikir harus ditempatkan sesuai porsi dan kepentingan masing-masing.

\footnotetext{
12 Huda.

${ }^{13}$ Wowo Sunaryo Kuswana, Taksonomi Berpikir (Bandung: PT. Remaja Rosdakarya, 2011), 23. Indonesian Journal of Islamic Education Studies (IJIES)

Volume 2, Nomor 2, Desember 2019 
Oleh karena itu, proses pembentukan pola pikir merupakan satu aspek yang paling strategis dalam pendidikan. ${ }^{14}$

Adapun ciri-ciri kemampuan berpikir kreatif menurut Azhari antara lain meliputi; Pertama, keterampilan berpikir lancar. Keterampilan berpikir lancar ini akan menghasilkan banyak jawaban dan gagasan yang relevan. Serta dapat menumbuhkan motivasi belajar yang tinggi dan memiliki arus pemikiran yang lancar. Kedua, keterampilan berpikir lentur (fleksibel). Keterampilan ini dapat menghasilkan gagasangagasan yang seragam serta mampu mengubah cara atau pendekatan yang nantinya akan menimbulkan arus pemikiran yang berbeda. Ketiga, keterampilan berpikir orisinil. Kemampuan mahasiswa untuk mengolah pikirannya ini akan menghasilkan beberapa jawaban yang tidak lazim. Kemampuan berpikirnya dalam ranah ini akan membuatnya memiliki jawaban yang lain daripada yang lain. Keempat, keterampilan berpikir terperinci. Keterampilan yang dimiliki mahasiswa ini akan berdampak pada pengembangan, penambahan maupun memperkaya suatu gagasan atau ide. Lain dari itu, seseorang yang memiliki keterampilan ini akan mampu untuk merinci detil-detail dan memperluas gagasan. ${ }^{15}$

Kecerdasan seseorang tidak selalu dinilai dari tingkat IQ (Intelligence Quotient) saja. Masing-masing individu dari peserta didik mempunyai kemajemukan dalam kecerdasannya. Artinya, setiap orang mempunyai pelbagai kecerdasan lain di samping IQ, misalkan emotional quotient (EQ) atau kecerdasan emosional, maupun spiritual quotient (SQ). Azhari dalam karyanya yang dipublikasikan oleh Jurnal Pendidikan Matematika, menyoroti pendapat seorang peneliti sekaligus penulis kenamaan asal Harvard University, Amerika Serikat, Howard Gardner yang menyatakan bahwa terdapat sembilan elemen yang mempengaruhi tingkat kecerdasan manusia. Ia menyebut elemenelemen tersebut sebagai multiple intelligence. ${ }^{16}$ Dalam karyanya "Peningkatan Kemampuan Berpikir Kreatif Matematik Siswa Melalui Pendekatan Konstruktivisme Di Kelas VII Sekolah Menengah Pertama (SMP) Negeri 2 Banyuasin III", Azhari menuliskan kesembilan hal tersebut, meliputi: pertama, kecerdasan musikal. intelegensi

\footnotetext{
${ }^{14}$ Imron Mustofa, "Pendidikan Islam Sebagai Institusi Politik Demokrasi Tertinggi di Indonesia", Halaqa: Islamic Education Journal, vol. 1, no. 1 (2017), 27-35. https://doi.org/10.21070/halaqa.v1i1.821

15 Azhari, "Peningkatan Kemampuan Berpikir Kreatif Matematik Siswa Melalui Pendekatan Konstruktivisme di Kelas VII Sekolah Menengah Pertama (SMP) Negeri 2 Banyuasin III”, Jurnal Pendidikan Matematika, vol. 7, no.2, 14. http://dx.doi.org/10.22342/jpm.8.1.992.1-12

${ }^{16}$ Farid Mashudi, Panduan Evaluasi dan Supervisi Bimbingan dan Konseling (Jogjakarta: DIVA Press, 2013), 79.
} 
ini mampu mendorong seseorang untuk lebih mudah dalam menghafal sekaligus mengikuti irama yang berkenaan dengan musik. Kedua, kecerdasan intrapersonal. Kecerdasan ini berhubungan dengan daya juang atau kemampuan bertahan, serti percaya diri. Kecerdasan ini menjaga seseorang untuk tetap giat dan serius dalam berusaha, tidak mudah gugup di depan umum, misalnya, berbicara di depan umum ataupun berinteraksi sosial. Ketiga, kecerdasan interpersonal. Inteligensi ini erat korelasinya dengan kualitas adaptasi, kerja sama, serta bersosial kemasyarakatan. Ia dapat dikembangkan melalui pemberian kesempatan dalam bergaul, bermain dan berkomunikasi. Hampir sama dengan kecerdasan sebelumnya, yang lebih menitik bertakan kepada pembelajaran di luar ruang dan berinteraksi dengan yang lainnya, ada juga kecerdasan keempat, visual spasial. Poin yang disebut terakhir sangat berhubungan dengan kualitas menilai atau cara pandang terhadap sesuatu. Kelima, kecerdasan natural. Keenam, kecerdasan kinestik tubuh. Ketujuh, kecerdasan moral. Kecerdasan ini berkenaan dengan berperilaku yang baik serta bisa menahan diri untuk tidak melakukan pelanggaran terhadap tata cara kesoanan. $\mathrm{Ke}$ delapan, kecerdasan verbal lingusitik. ${ }^{17}$

\section{Gejala Jiwa Manusia dan Tipe Kepribadian Manusia}

Sebelum melangkah kepada penyelesaian permasalahan mahasiswa PTAIN, ada baiknya apabila kita mengetahui gejala-gejala jiwa yang dimiliki setiap manusia. tentunya manfaat dari kita mengetahui gejala jiwa ini ialah agar kita bisa mengetahui aktifitas apa saja yang setiap detiknya berproses di dalam jiwa kita. Hal ini tentunya berpengaruh terhadap perkembangan pemikiran kita dan juga berpengaruh terhadap ke efektifan belajar mahasiswa. Tidak hanya gejala jiwa saja yang akan dipaparkan oleh penulis, namun mengetahui karakter diri masing-masing individu akan dibahas disini. Sekali lagi, sebelum menginjak kepada penyelesaian masalah yang nantinya akan diberikan oleh konselor, ada baiknya kita mengetahui karakter apa saja yang dimiliki setiap individu.

Dalam kehidupannya manusia selalu melakukan aktifitas, dan dalam melaksanakan aktifitas tersebut alat-alat kejiwaan dalam diri manusia bekerja. Alat-alat kejiwaan tersebut saling mengisi dan berkaitan antara satu dengan lainnya, baik bersifat fisik maupun psikis, baik jasmaniah maupun rohaniah. ${ }^{18}$ Banyak istilah yang dipakai dalam menyebut aktifitas psikis atau rohaniah, terdapat beberapa peneliti yang

\footnotetext{
${ }^{17}$ Mashudi, 79-81.

${ }^{18}$ Huda, Psikologi Belajar, 23.
} 
menyebutnya peristiwa-peristiwa jiwa, fungsi-fungsi jiwa maupun gejala jiwa. Penulis akan menggunakan istilah gejala jiwa untuk memudahkan dalam pemahaman. Terdapat beberapa golongan dalam gejala jiwa seseorang. Aristoteles membagi gejala-gejala jiwa seseorang menjadi dua golongan yaitu, golongan yang pertama mengandung kekuatan mengenal (kognisis) dan golongan kedua mengandung kekuatan kemauan (konasi). ${ }^{19}$

Bigot dan Failand dalam buku yang berjudul Learboek der Psychologis menjelaskan pengertian gejala jiwa tersebut sebagai berikut; 1) Gejala kognisi, ialah suatu kemampuan jiwa untuk mengenal segala sesuatu yang di dalamnya terdapat aktifitas jiwa, yaitu pengamatan, tanggapan, fantasi, ingatan, berpikir dan inteligensi. 2) Gejala emosi, ialah kemampuan jiwa untuk merasakan segala sesuatu yang disebabkan oleh perangsang dari luar dan dari dalam dirinya antara lain perasaan ketuhanan, perasaan estetika, perasaan kesusilaan dan lain-lain. ${ }^{20}$ Untuk lebih jelasnya, kami akan merinci masingmasing aktifitas jiwa tersebut. Gejala Kognitif memiliki aktifitas jiwa di antaranya; pertama, pengamatan: proses awal terjadinya pengamatan ialah ketika adanya perangsang yang mengenai alat indera. Proses ini disebut proses fisik, karena terjadinya proses tersebut berdasarkan kekuatan alam. Sedangkan syarat-syarat terjadinya pengamatan ialah, harus ada perhatian obyek yang diamati, ada perangsang yang diterima oleh indera, urat syaraf sensoris akan membawa ke otak, dan muncullah kesadaran terhadap perangsang itu. ${ }^{21}$

Kedua, tanggapan. Tanggapan biasanya didefinisikan sebagai bayangan yang tinggal dalam ingatan setelah kita melakukan pengamatan. ${ }^{22}$ Sebenarnya tidak hanya bayangan saja yang tinggal dalam ingatan. Akan tetapi, tanggapan juga merupakan suatu reaksi atas apa yang telah kita amati. Dalam arti lain, tanggapan adalah upaya kita untuk menghidupkan sesuatu yang telah kita amati (di masa lampau), tidak hanya di masa lampau saja, akan tetapi kita juga dapat mengantisipasi yang akan datang atau mewakili yang sekarang. Ketiga, fantasi. Fantasi adalah daya jiwa untuk membentuk tanggapantanggapan atau bayangan-bayangan baru dengan pertolongan tanggapan-tanggapan yang sudah ada. ${ }^{23}$ Fantasi pada umumnya merupakan aktivitas menciptakan. Maksudnya ialah, fantasi menciptakan yaitu jenis fantasi yang menciptakan sesuatu.

\footnotetext{
${ }^{19}$ Bahrudin, Psikologi Pendidikan Refleksi Terhadap Fenomena (Yogyakarta: Ar-Ruzz, 2007), 84.

${ }^{20}$ L.C.T. Bigot dan R.G. Failand, Learboek der Psychologis (Groningen: J.B Wallers, 1950), 32.

${ }^{21}$ Zuhairi, Ilmu Jiwa Umum (Malang: Biro Ilmiyah FT IAIN Sunan Ampel, 1980), 59.

22 Bigot dan Failand, Learboek der, 72.

${ }^{23}$ Sumadi Suryabrata, Psikologi Pendidikan (Jakarta: Rajawali, 1987), 39.
} 
Keempat, ingatan. Ingatan merupakan alih bahasa dari memory. Karena itu di samping ada yang menggunakan istilah ingatan, ada pula yag menggunakan istilah memori. Ingatan berhubungan dengan pengalaman-pengalaman yang telah lampau, sesuatu yang pernah dialami atau dipersepsinya. ${ }^{24}$ Namun demikian, ingatan tidak hanya mampu menyimpan apa yang pernah dialaminya saja, tetapi juga meliputi kemampuan untuk menerima, menyimpan dan menimbulkan kembali. Kelima ialah berpikir. Berpikir yang sebenarnya adalah suatu aktivitas pribadi yang bertujuan untuk memecahkan sesuatu problem sehingga menemukan hubungan-hubungan dan menentukan sangkut pautnya. ${ }^{25}$ Dalam berpikir manusia diarahkan kepada suatu problem untuk mencari jalan pemecahannya. Dalam berpikir pula manusia memerlukan persamaan-persamaan dan perbedaan antara masalah yang satu dengan yang lainnya.

Gejala emosi (perasaan) pada umumnya bersangkutan dengan fungsi mengenal. Artinya, perasaan dapat timbul karena mengamati, menangkap, atau mengkhayalkan, mengingat-ingat atau memikirkan sesuatu. ${ }^{26} \mathrm{Di}$ dalam jiwa tersebut tentunya terdapat kekuatan. Kekuatan yang menghantarkan seseorang kepada capaian yang dituju. Menurut Ki Hajar Dewantara dalam bukunya, beliau menyebutkan bahwa kemampuan jiwa seseorang menjadi tiga golongan besar, yang sering dikenal sebagai pembagian yang trichomis. Juga dikemukakan oleh Ki Hajar Dewantara sebagai berikut:

Kini baiklah apabila kita ketahui adanya tiga bentuk kekuatan yang ada dalam jiwa manusia pada umumnya. Tiga kekuatan atau "trisakti" jiwa itu adalah pikiran, rasa dan kemauan. Pendapat ilmu jiwa atau psikologi sungguh sesuai dengan apa yang terkenal pula dalam ilmu jiwa ketimuran yang menyebutkan adanya cipta, rasa dan karsa. ${ }^{27}$

Dapat kita pahami di atas bahwa kekuatan tersebut tergolong pikiran, rasa dan kemauan. Termasuk dalam urusan belajar pun kita seharusnya memiliki tiga bentuk kekuatan tersebut. Apabila tidak kita temukan tiga kekuatan tersebut, maka jiwa kita pun melemah dan kondisi belajar tidak akan bisa kita lalui dengan baik. Selain memahami kondisi jiwa seseorang, tentunya kurang lengkap apabila kita belum mengetahui karakter diri setiap individu. Maka penjelasan selanjutnya akan mengarah kepada macam-macam kepribadian seseorang.

\footnotetext{
${ }^{24}$ Huda, Psikologi Belajar, 40.

${ }^{25}$ Huda, 44.

${ }^{26}$ Huda, 48.

${ }^{27}$ Ki Hajar Dewantara, Karya K.H. Dewantara (Yogyakarta: Majlis Luhur Taman Siswa, 1962), 430. Indonesian Journal of Islamic Education Studies (IJIES)

Volume 2, Nomor 2, Desember 2019 
Ada beberapa tipe kepribadian yang mungkin bisa kita jadikan acuan untuk mengenal pribadi kita, yaitu sanguinis, kolerik, melankolis dan plegmatis. ${ }^{28}$ Tentu saja tidak ada manusia yang persis mewakili satu tipikal kepribadian tersebut. Bahkan mungkin semua tipe di atas ada pada diri kita. Akan tetapi, tipe-tipe paling dominan ada pada diri kita itulah tipikal kepribadian kita. Penulis akan memaparkan masing-masing tipe tersebut dengan kelebihan dan kekurangan yang terletak pada masing-masing tipe di atas.

Untuk tipe kepribadian yang pertama adalah; Sanguinis. Sanguinis ini biasa diidentifikasikan kepada pribadi yang cenderung periang. Kelebihan dari pribadi ini adalah periang, banyak bicara, ramah, bersemangat, suka bergaul, bersahabat, mudah percaya dengan orang lain, optimis, sangat menonjol dalam hal berbelas kasihan (baik hati), murah hati, cenderung tulus dan murni serta mudah memaafkan. Tentunya tipe ini memiliki kekurangan pula, kekurangan tersebut di antaranya. Terkadang tipe sanguinis ini memiliki karakter kepribadian yang gelisah, berkemauan lemah, tidak disiplin, pelupa, bergerak dulu baru berpikir dan tidak teliti. ${ }^{29}$

Selanjutnya ialah tipe kepribadian kolerik. Kolerik ini lebih kepada jiwa pemimpin yang dia punya. Kelebihan dari kolerik ini dia berkemauan kuat, berkomitmen tinggi, berjiwa bebas dan sangat optimis. Orang koleris cenderung tekun, ulet, gigih, berbakat dan suka memimpin. Namun, si kolerik ini mempunyai kekurangan, kekurangan tersebut di antaranya; ia terkesan kasar, menguasai atau mendominasi orang lain, berbicara dengan nada memerintah atau menekan. Orang koleris mudah marah, berbangga diri. Untuk tipe melankolis ini cenderung berbakat, cermat, peka, lembut, perfeksionis (mengejar kesempurnaan), suka keindahan, idealis dan rela berkorban. Tetapi ada beberapa kekurangan dari kepribadian ini, orang melankolis cenderung pemurung, menila negatif, teoritis, tidak ramah, suka mencela, kaku dan pendiam. ${ }^{30}$

Tipe kepribadian terakhir adala Plegmatis. Plegmatis termasuk seorang follower yang setia. Oleh karena itu dia mudah diandalkan dan dapat menjadi tangan kanan. Orang plegmatis lemah lembut dan tenang, emosinya stabil, detail dan produktif. Plegmatis orang yang praktis, berbeda dengan melankolis yang cenderung teoritis. Plegmatis juga memiliki bakat memimpin, berbicara diplomatis (karena pembawaannya yang tenang). Namun ada beberapa kekurangan dari orang plegmatis. Dia cenderung penakut,

\footnotetext{
${ }^{28}$ Mashudi, Panduan Evaluasi, 69.

${ }^{29}$ Mashudi, 69-70.

${ }^{30}$ Mashudi, 70-71.
} 
melindungi diri sendiri, suka mencari argumen bahwa dia benar. ${ }^{31}$ Dengan kita mengetahui tipe kepribadian masing-masing orang, kita bisa lebih tahu minat dan pembawaan yang ia miliki. Jika sudah seperti itu, kita akan lebih mudah untuk mendekati dan memberikan konseling kepadanya. Kita sudah mengetahui kelebihan dan kekurangan yang ada pada dirinya, meskipun hal ini tidak seratus persen dijadikan tolak ukur untuk mengetahui kepribadian seseorang. Namun setidaknya kita bisa sedikit membaca akan kepribadian yang ia miliki.

\section{Penyelesaian Masalah}

Secara mendasar sistem pendidikan di Perguruan Tinggi Agama Islam Negeri (PTAIN) yang mengharuskan peserta didiknya untuk mampu terlibat aktif secara mandiri turut menjadi faktor yang mengharuskan mereka mampu beradaptasi secara cepat dan tepat. Tekanan ini tentu memberikan dampak yang berlainan bagi masing-masing individu. Mereka dapat beradaptasi akan mampu bersaing, sebaliknya yang gagal akan menemui pelbagai hambatan. Kaitannya dengan sistem pendidikan di perguruan tinggi persoalan ini akan berdampak pada perubahan cara belajar yang ada pada diri masingmasing peserta didik. Perubahan ini dialami hampir oleh seluruh mahasiswa, tidak terkecuali PTAIN. Untuk menyebut contoh, jika di tingkat menengah atas, umumnya para murid diajarkan dengan gaya belajar terbimbing atau diarahkan oleh guru, maka dalam kasus perguruan tinggi mahasiswa lebih dipancing untuk dapat mandiri.

Perubahan pola belajar turut juga membawa perubahan kondisi kejiwaan mahasiswa. Tidak jarang dari perubahan sistem pembelajaran ini menyebabkan goncangan pada kepribadian. Kepribadian yang tergoncang lambat laun menimbulkan berkurangnya rasa percaya diri dan tidak menutup kemungkinan terjadinya sikap menarik diri dari masyarakat. Jika hal ini berlanjut maka sangat mungkin akan berakhir pada terputusnya pendidikan di perguruan tinggi. Ini terjadi sebagai dampak kurangnya persiapan mereka dalam menghadapi dampak perkembangan zaman. Jika mereka yang gagal beradaptasi terancam memiliki kepribadian introvert, maka sebaliknya mereka yang tidak mampu mengendalikan perubahan akan terlena dengan kegiatan kemahasiswaan. Kelalaian ini menyebabkan kegagalan dalam memprioritaskan aktivitas satu wajib dari yang komplementer.

\footnotetext{
${ }^{31}$ Mashudi, 72.
} 
Kehadiran dosen dalam hal dosen berperan sebagai pembimbing yang pro aktif dalam mengarahkan pola pikir mahasiswa. Dosen diharapkan mampu mengerti dan memahami segala persoalan yang dihadapi mahasiswa. Dengan pemahaman semacam ini, dosen diharapkan mampu tampil sebagai penyeimbang segala persoalan yang dihadapi mahasiswa. Seorang pembimbing yang dapat mengerti kebutuhan mahasiswa sekaligus memahami tantangan yang mereka hadapi akan mampu menyuguhkan solusi paling efektif dan efisien. Hadirnya dosen semacam ini akan mampu membantu mahasiswa di PTAIN dalam beradaptasi dengan "lingkungan" baru di dunia mereka. ${ }^{32}$

Kehadiran dosen dengan kemampuan sebagai pembimbing yang baik akan memicu minat dan bakat mahasiswa. Tidak menutup kemungkinan dengan hadirnya dosen semacam ini akan memunculkan sifat mahasiswa akan lebih terbuka, merasa nyaman dan aman dalam berkomunikasi yang akhirnya akan menjadikan dosen tersebut sebagai panutan. Kenyamanan dan keterbukaan seorang mahasiswa dalam berkomunikasi mengenai pelbagai persoalan akademis maupun non akademis akan menghadirkan pola pikir yang lebih mampu beradaptasi terhadap perkembangan zaman. Hal semacam inilah sebenarnya yang merupakan tugas pokok dari hadirnya dosen.

Pembimbingan terhadap persoalan yang dihadapi mahasiswa merupakan proses menghadirkan jawaban sekaligus pendidikan kepada mereka dalam menghadapi segala persoalan yang mungkin akan muncul di kemudian hari. Dalam lingkup yang lebih detail hal ini akan membantu pengembangan kualitas diri mahasiswa dalam menghadapi persoalan akademis, non akademis bahkan problematika pribadi dan sosial kemasyarakatan. Pemberian pimbingan terhadap mahasiswa dapat berupa banyak hal, seperti pengarahan akademik, bimbingan konseling maupun pengarahan potensi pekerjaan yang dapat digapai. ${ }^{33}$

Sebelum menginjak kepada penyelesaian permasalahan, ada baiknya apabila kita mengetahui fungsi dan tujuan adanya bimbingan mahasiswa. Bimbingan mahasiswa memiliki beberapa fungsi di antaranya, pembekalan pengenalan dan pemahaman yang lebih mendalam tentang kondisi, potensi dan karakteristik mahasiswa, membantu menyesuaikan diri dengan kehidupan di perguruan tinggi, membantu mengatasi problema-problema akademik dan problema sosial-pribadi yang berpengaruh terhadap perkembangan akademik mahasiswa. ${ }^{34}$

\footnotetext{
${ }^{32}$ Faizah Noer Laila, Bimbingan Konseling Sosial (Surabaya: UIN Sunan Ampel Press, 2014), 100.

${ }^{33}$ Achmad Juntika Nurihsan, Bimbingan dan Konseling (Bandung: PT. Refika Aditama, 2011), 29.

${ }^{34}$ Nurihsan.
} 
Sedangkan adanya bimbingan mahasiswa bertujuan untuk memberikan layanan bimbingan, yang mana dalam bimbingan tersebut diharapkan mahasiswa mampu dalam menyelesaikan perkuliahan. Selain itu, diharapkan pula mahasiswa mampu memilih program studi atau konsentrasi mata kuliah yang sesuai dengan bakat, minat dan cita-cita mereka. Bimbingan mahasiswa bertujuan untuk membentuk mahasiswa menjadi pribadi yang nantinya bisa memperoleh prestasi belajar yang sesuai dengan kemampuan mereka, mampu membina hubungan sosial dengan sesama mahasiswa dan dosen dengan baik. Lain daripada itu, diharapkan mahasiswa memiliki sikap dan kesiapan yang profesional serta memiliki pandangan yang realistis tentang diri dan lingkungannya. ${ }^{35}$

Dalam bab ini penulis akan memaparkan pula dua model bimbingan konseling guna memberikan penguat atas pemecahan permasalahan yang dihadapi dan penerapannya sesuai dengan permasalahan yang diangkat. Model bimbingan yang pertama ialah, model parsonian. Model bimbingan ini merupakan model bimbingan yang berupaya menjodohkan (Matching) karakteristik (kemampuan, minat dan temperamen) individu dengan syarat-syarat yang dituntut suatu pekerjaan (okupasi). ${ }^{36}$ Tuntutan pekerjaan disini ialah perkuliahan yang dilaksanakan mahasiswa tersebut. Di dalam model bimbingan ini terdapat satu proses antara klien dan konselor. Proses tersebut ialah man analysis. Dalam hal ini konselor bersama klien bersama-sama menganalisis kapabilitas, minat dan tempramen klien.

Model bimbingan yang kedua ialah, model bimbingan identik dengan pendidikan. Model ini bertujuan untuk mempersiapkan para peserta didik agar mampu melakukan aktivitas-aktivitas bermakna melalui pendidikan. Sama halnya model bimbingan yang pertama, di dalam model bimbingan kedua ini terdapat pula proses yang seharusnya dilakukan klien dan konselor. Beberapa proses tersebut adalah: 1) klien dibimbing dalam upaya pemecahan masalah, menyelesaikan suatu tugas atau meraih tujuan. 2) bimbingan harus bersifat simpatik, bersahabat dan pemahaman, 3) Konselor harus memiliki pengalaman, pengetahuan dan kebijakan, 4) klien yang dibimbing secara progresif menerima bimbingan dan mengambil keputusannya sendiri, 5) bimbingan yang diberikan kepada klien hendaknya menjadi suatu petunjuk bagi si klien agar dapat membimbing diri sendiri secara lebih baik. ${ }^{37}$

\footnotetext{
${ }^{35}$ Nurihsan.

${ }^{36}$ Syamsu Yusuf, Landasan Bimbingan dan Konseling (Bandung: PT. Remaja Rosdakarya, 2005), 45.

${ }^{37}$ Laila, Bimbingan Konseling, 107.
} 
Selain itu, ada pula beberapa ragam bimbingan untuk mahasiswa. Dalam hal ini, penulis akan memaparkan ruang lingkup bimbingan mahasiswa yang terdiri dari tiga ruang lingkup. Ruang lingkup pertama, ruang lingkup ini merupakan layanan utama dari bimbingan mahasiswa. Berbagai faktor yang bersifat non-akademis yang menjadi permasalahan mahasiswa juga akan berpengaruh terhadap kegiatan akademis mereka. Bimbingan akademis dapat difokuskan ke dalam upaya membantu mahasiswa dalam halhal berikut; 1) penentuan program studi tiap semester, 2) penyelesaian studi dalam setiap mata kuliah. ${ }^{38}$ Dalam menempuh mata kuliah mahasiswa sering menghadapi masalah dan kesulitan dalam menyelesaikan tugas-tugas, memilih metode dan sumber belajar.hal lain yang pasti dirasakan mahasiswa adalah menyesuaikan diri terhadap tuntutan lain yang terkait dengan mata kuliah yang diikutinya. 3) dorongan menyelesaikan tugas akhir. ${ }^{39}$ Sering kali hambatan mahasiswa dalam menyelesaikan studi disebabkan oleh keterlambatan penyelesaian tugas akhir. Hal ini karena mereka kurang memiliki motif dan kemampuan membagi waktu terhadap penyelesaian tugas akhirnya. Untuk itu, para mahasiswa perlu mendapatkan bimbingan.

Kedua, bimbingan dalam pembentukan sifat dan perilaku bertanggung jawab secara profesional. Pengarahan pengembangan sikap dan perilaku merupakan hal yang penting, sebab sebagian mahasiswa sering menunjukkan gejala kurangnya rasa tanggung jawab. Lembaga pendidikan tinggi sering kali mendapat tuntutan untuk menyediakan sumber daya manusia yang unggul, bertanggung jawab dan berdaya saing. Oleh karena itu, sumber daya manusianya harus ditanami sikap mentalitas semacam ini. Harapannya mereka akan memiliki kesiapan diri untuk menjadi seorang profesional dalam bidang tertentu. Pembentukan tenaga ahli semacam ini selain dilakukan selama proses perkuliahan dalam kelas, juga didukung dengan proses pendidikan di luar kelas. Poin yang disebut terakhir, memiliki nilai lebih, sebab setiap teori yang diperoleh dalam kelas akan diaktualisasikan ataupun diuji kebenarannya dalam bentuk pengalaman secara langsung. Tentunya kedua proses ini hanya bisa dilaksanakan secara maksimal, selama didukung oleh kualitas akademisi dan mentalitas yang baik. Oleh karena itu, untuk memperoleh kesiapan diri semacam itu mahasiswa perlu dibina secara intens dengan disertai pengalaman-pengalaman yang mendukung. Selanjutnya mahasiswa dituntut untuk memperkaya wawasan bidang profesinya melalui pelbagai kegiatan lain. ${ }^{40}$

\footnotetext{
${ }^{38}$ Nurihsan, Bimbingan, 33.

${ }^{39}$ Nurihsan, 34.

${ }^{40}$ Nurihsan, 35.
} 
Ketiga, bimbingan peyesuaian sosial dan pribadi. Dalam mengikuti dan menyelesaikan studinya, mahasiswa sering kali menghadapi berbagai masalah sosial dan pribadi yang cukup berpengaruh terhadap proses studinya. Sesuai dengan permasalahan yang sering timbul, mahasiswa perlu mendapatkan bimbingan dalam beberapa hal. Mahasiswa didorong untuk melakukan penyesuaian diri terhadap suasana kehidupan perguruan tinggi (terutama untuk mahasiswa baru), diadakan pembinaan dan pemeliharaan motif, serta gairah untuk belajar secara kreatif dan produktif, menghindarkan dan menyelesaikan konflik, baik dengan teman, dosen maupun anggota keluarga, penyesuaian diri terhadap lingkungan dan tempat tinggal, penyelesaian konflik antara keinginan studi dan pemenuhan tugas pekerjaan dan keluarga. ${ }^{41}$

Terdapat beberapa prosedur bimbingan mahasiswa yang bisa dilakukan. Antara lain; 1) tahap-tahap bimbingan. 2) mekanisme layanan bimbingan. Mekanisme ini mencakup alur kegiatan sejak penerimaan mahasiswa, bahkan sejak seleksi calon mahasiswa. 3) teknik-teknik bimbingan. Sejalan dengan mekanisme dan tahap bimbingan tersebut, teknik-teknik berikut dapat dipilih dan digunakan secara tepat: teknik disuksi kelompok yang bersifat orientasi, mencakup diskusi tentang program studi, kurikulum, personalia akademis dan proses belajar mengajar yang diterapkan dalam pelaksanaan program studi; teknik diskusi kelompok yang bersifat bantuan mencakup diskusi tentang permasalahan belajar, sosial dan pribadi; teknik kegiatan kelompok lain, baik yang bersifat orientasi maupun bantuan; konsultasi perorangan untuk menangani masalahmasalah akademis; konseling perorangan untuk menangani masalah-masalah sosialpribadi; pembahasan kasus yaitu pembahasan mahasiswa dengan permasalahannya bersama-sama dengan personalia akademis lain untuk menemukan jalan keluar dalam membantu mahasiswa; rujukan bagi mahasiswa yang menghadapi kesulitan sosialpribadi yang tidak dapat ditangani oleh personalia akademis yang ada di fakultas. ${ }^{42}$

\section{Pembimbing/Konselor}

Untuk dapat memberikan layanan bimbingan mahasiswa yang tepat sesuai dengan sifat dan problema yang dihadapi mahasiswa, baik jenis maupun kedalamannya, dituntut adanya pelaksanaan bimbingan yang memiliki kualifikasi dengan jumlah yang memadai, serta penugasan yang jelas. Maka dari itu, terdapat beberapa syarat-syarat untuk seorang pembiimbing yang nantinya bisa menjadi konselor bagi mahasiswanya. Adanya

\footnotetext{
${ }^{41}$ Nurihsan.

${ }^{42}$ Nurihsan, 38.
} 
pembimbing yang memiliki kualitas kepribadian yang memadai menjadikan bimbingan yang dilaksanakan bersama mahasiswanya menjadi bimbingan yang efisien dan efektif. Kualitas kepribadian tersebut juga harus diimbangi dengan pengetahua-pengetahuan yang dimiliki, serta memiliki keahlian profesional tentang bimbingan.

Terdapat dua kategori dalam memenuhi syarat-syarat sebagai pembimbing. Di antaranya; 1) syarat kualitas kepribadian dan dedikasi. Syarat ini mencakup nilai-nilai kepribadian diri seorang pembimbing. Bertaqwa kepada Allah, menunjukkan keteladanan dalam hal yang baik, dapat dipercaya, jujur, konsisten, memiliki rasa kasih sayang dan kepedulian kepada mahasiswa, rela dan tanpa pamrih dalam memberikan layanan bimbingan kepada mahasiswa dan senantiasa melengkapi diri dengan pengetahuan dan informasi yang berkaitan dengan keperluan bimbingan. ${ }^{43}$ 2) Syarat kualifikasi. Pada tingkat universitas ada satu tim Bimbingan dan Konseling (BK) yang terdiri atas para ahli bimbingan dan pihak-pihak terkait. Tim ini terdiri atas seorang koordinator berpendidikan S3 BK dan berpangkat minimal lektor (golongan IV/b) dan sejumlah anggota tim yang sekaligus menjadi tim BK fakultas. ${ }^{44}$

Selain adanya syarat-syarat di atas, ada pula rasio pembimbing dengan mahasiswa. Adapun rasio anggota tim BK (konselor) dengan mahasiswa disesuaikan dengan jumlah tenaga yang ada serta permasalahan yang dihadapi. Untuk memungkinkan mahasiswa menerima dan dosen memberi layanan serta bimbingan dengan baik, khsususnya dalam bidang akademik pada tingkat jurusan. Rasio Dosen Pembimbing Akademik (DPA) dengan mahasiswa 1:20. ${ }^{45}$

Dalam sebuah konseling antara konseli (mahasiswa) dengan konselor (DPA), hendaknya melakukan teknik-teknik konseling yang baik. Agar konseling antara mahasiswa dengan Dosen Pembimbing Akademik bisa terjalin dengan baik. Beberapa teknik konseling di antaranya; 1) melayani (attending), melayani klien secara pribadi merupakan upaya yang harus dilakukan oleh konselor dalam memberikan perhatian secara total kepada klien. Hal ini ditampilkan melalui sikap tubuh dan ekspresi wajah. 2) empati, empati dapat diartikan sebagai kemampuan konselor untuk dapat merasakan dan menempatkan dirinya di posisi klien. 3) refleksi, secara sederhana refleksi dapat diartikan sebagai upaya konselor memperoleh informasi leboh mendalam tentang apa yang dirasakan oleh klien dengan cara memantulkan kembali perasaan, pikiran dan

\footnotetext{
${ }^{43}$ Nurihsan, 30.

44 Nurihsan.

45 Nurihsan, 31.
} 
pengalaman klien.dalam hal ini konselor dituntut untuk menjadi pendengar yang aktif. 4) eksplorasi. Eksplorasi merupakan suatu keterampilan konselor untuk menggali perasaan, pikiran dan pengalaman klien. DPA disini harus benar-benar pandai mengesplorasikan dirinya kepada mahasiswa yang di bimbingnya. Karena dalam hal ini, DPA bisa mengetahui lebih jelas dan rinci, problem apa saja yang dihadapi oleh mahasiswanya. Di sisi lain, cara DPA bereksplorasi inilah yang membuat mahasiswa lebih terbuka kepada DPA. 5) memberi nasihat. Hal ini harus lebih diperhatikan. Terkadang mahasiswa akan merasa sangat risih apabila mahasiswa tersebut mencurahkan segala problemnya kepada seorang DPA, lalu belum selesai penyampaian itu, seorang DPA ini memotongnya dengan nasihat-nasihat panjang. Inilh yang membuat mahasiswa terkadang risih atau kurang nyaman. Ada baiknya apabila nasihat-nasihat tersebut disampaiakn apabila mahasiswa telah selesai menyampaikan permasalahannya. ${ }^{46}$

\section{Kesimpulan}

Hadirnya faktor internal dan eksternal akan sangat mempengaruhi perubahan proses kematangan seorang individu. Bagi seorang mahasiswa di perguruan tinggi, perubahan yang terjadi harus bisa diarahkan dengan tepat dan efektif. Mahasiswa dituntut mampu menyesuaikan dirinya terhadap pelbagai perubahan tersebut. Sebab kemampuan beradaptasi akan memunculkan cara pandang yang positif dan optimis, guna mengaktualisasikan seluruh potensi yang ada pada dirinya. Atmosfir pendidikan di perguruan tinggi pastinya berbeda dengan tingkat sekolah sebelumnya. Perbedaan ini paling kentara terletak pada pemberian kebebasan dalam mengaktualisasikan diri. Kebebasan mengharuskan jiwa mandiri yang dituangkan dalam bentuk sikap pro aktif dalam melacak segala informasi, berpikiran kritis dan tahan banting serta didukung oleh kualitas moral yang baik, utamanya dalam menghadapi segala perubahan yang ada. Hal ini tentunya juga perlu dukungan dari pembimbing yang mampu mengarahkan dan memberi kekuatan mental dan pematangan motivasi, agar mahassiswa dapat mengaktualisasikan diri dengan baik.

\footnotetext{
${ }^{46}$ Namora Lumongga Lubis, Memahami Dasar-Dasar Konseling Dalam Teori Dan Praktik (Jakarta: Prenada Media Group, t.th.), 92-101.
} 


\section{Daftar Pustaka}

Ahmadi, Abu, Aziz, Ahmad Amir dan Supriyono, Widodo. Psikologi Belajar. Jakarta: Rineka Cipta, 2004.

Azhari, "Peningkatan Kemampuan Berpikir Kreatif Matematik Siswa Melalui Pendekatan Konstruktivisme Di Kelas VII Sekolah Menengah Pertama (SMP) Negeri 2 Banyuasin III", Jurnal Pendidikan Matematika, vol. 7, no. 2. http://dx.doi.org/10.22342/jpm.8.1.992.1-12

Bahrudin, Psikologi Pendidikan Refleksi Terhadap Fenomena. Yogyakarta: Ar-Ruzz, 2007.

Bigot, L.C.T. dan Failad, R.G. Learboek der Psychologis. Groningen: J.B Wallers, 1950.

Dewantara, Ki Hajar. Karya K.H. Dewantara. Yogyakarta: Majlis Luhur Taman Siswa, 1962.

Huda, M. Musthofa. Psikologi Belajar. Surabaya: UIN Sunan Ampel Pres, 2014.

Indonesia, Departemen Agama Republik. Sejarah Institusi Agama Islam Negeri (IAIN).

Kiswoyo, Anggi. Wawancara (Surabaya, 15 Novermber 2019).

Kuswana, Wowo Sunaryo. Taksonomi Berpikir. Bandung: PT. Remaja Rosdakarya, 2011.

Laila, Faizah Noer. Bimbingan Konseling Sosial. Surabaya: UIN Sunan Ampel Press, 2014.

Lubis, Namora Lumongga. Memahami Dasar-Dasar Konseling dalam Teori dan Praktik. Jakarta: Prenada Media Group, t.th.

Mashudi, Farid. Panduan Evaluasi dan Supervisi Bimbingan Dan Konseling. Jogjakarta: DIVA Press, 2013.

Mustofa, Imron. "Gagasan Islamisasi Ilmu (Studi tentang kerangka metodologi Institute for the Study of Islamic Thought and Civilization (INSISTS))". Disertasi---UIN Sunan Ampel Surabaya, 2019.

------. "Pendidikan Islam Sebagai Institusi Politik Demokrasi Tertinggi di Indonesia", Halaqa: Islamic Education Journal, vol. 1, no. 1. 2017. https://doi.org/10.21070/halaqa.v1i1.821

Nurihsan, Achmad Juntika. Bimbingan dan Konseling. Bandung: PT. Refika Aditama, 2011.

Permata, Zulfa. Wawancara (Surabaya, 15 November 2019).

Stanton, Charles Michele. Pendidikan Tinggi Islam. Jakarta: Logos, 1998.

Suryabrata, Sumadi. Psikologi Pendidikan. Jakarta: Rajawali, 1987. 
Bimbingan Koseling..., Imron Mustofa \& Moch. Kalam Mollah

Yusuf, Syamsu. Landasan Bimbingan dan Konseling. Bandung: PT. Remaja Rosdakarya, 2005.

Zuhairi, Ilmu Jiwa Umum. Malang: Biro Ilmiyah FT IAIN Sunan Ampel, 1980. 